\title{
Assessment of plankton diversity of Tlawng River at Reiek Kai in Mizoram, Northeast India
}

\author{
Esther Lalhmingliani*, Lalhminghlua \\ Department of Zoology, Mizoram University, Tanhril 796004, Mizoram, India
}

Corresponding author: esther19ralte@gmail.com

\begin{abstract}
Plankton diversity of Tlawng River at Reiek kai in Mizoram, Northeast India, was investigated during 2017 to 2018. A total of 16 genera of phytoplankton belonging to 10 orders and 5 groups, and 7 genera of zooplanktons belonging to 7 orders and 5 groups were encountered. The phytoplankton group consisted of Chlorophyceae, Zygnematophyceae, Cyanophyceae, Bacillariophyceae and Ulvophyceae. Bacillariophyceae were the predominant component of phytoplankton in Tlawng River during all seasons in terms of numerical abundance and account for $60 \%$ of the total phytoplankton. Majority of the phytoplankton were encountered during the summer season. The zooplankton group consisted of Copepoda, Tubulinea, Branchiopoda, Rotifera and Nematoda. Of these, the class Copepoda were found to be the most dominant constituting $59 \%$ of the total zooplankton population encountered during the sampling period. The least dominant group among the zooplankton were Tubulinea constituting only $4 \%$ of the total zooplankton population. Unlike the phytoplankton where summer season harboured maximum number of individuals, the zooplanktons were encountered mostly during the winter season.
\end{abstract}

Keywords: Phytoplankton, zooplankton, Tlawng river, Mizoram.

\section{INTRODUCTION}

Plankton is a collective term for various organisms that drift in the open water of the sea or freshwater, lakes and ponds (Thurman, 1997). They constitute an important component of the pelagic community and are one of the most rapid detectors of environmental change through their quick response to toxins and other chemicals (Needham, 1972). The planktons are moved by currents and are easily affected by the presence of favorable condition, which serves as a convenient index to the pelagic community and thus depicts the condition of the area (Latha, 2014).

The sensitivity and fluctuation in plankton species composition are usually a suitable explanation to demonstrate the alteration within an ecosystem (Biligrami, 1988). Normally, it is found that any slight alteration in environmental status can change diversity until there is no adaptation or gene flow from nonadaptive sources. The present work deals with the diversity and distribution pattern of plankton in Tlawng river at Reiek Kai, one of the longest rivers in Mizoram.

\section{Materials AND Methods}

The water samples were collected from Tlawng river at Reiek Kai at monthly intervals from August 2017 to May 2018. The planktons were collected by submerging the plankton net to a maximum depth covering as much area as possible. The planktons thus collected at the tube from the end of the net were transferred to the sample bottle and then fixed with formalin (i.e. $1 \%$ of the total volume of the sample collected).

The samples were then brought to the laboratory, Department of Zoology, Mizoram University, for qualitative and quantitative analyses. The water samples were dropped on slides and were then observed under microscope for the assessment of plankton diversity. All individuals present in the sample were counted and photograph was taken. The identification of different plankton was done as per the keys provided by Fristch (1935), Davies (1955), Edmondson (1959), Prescott (1964) and 


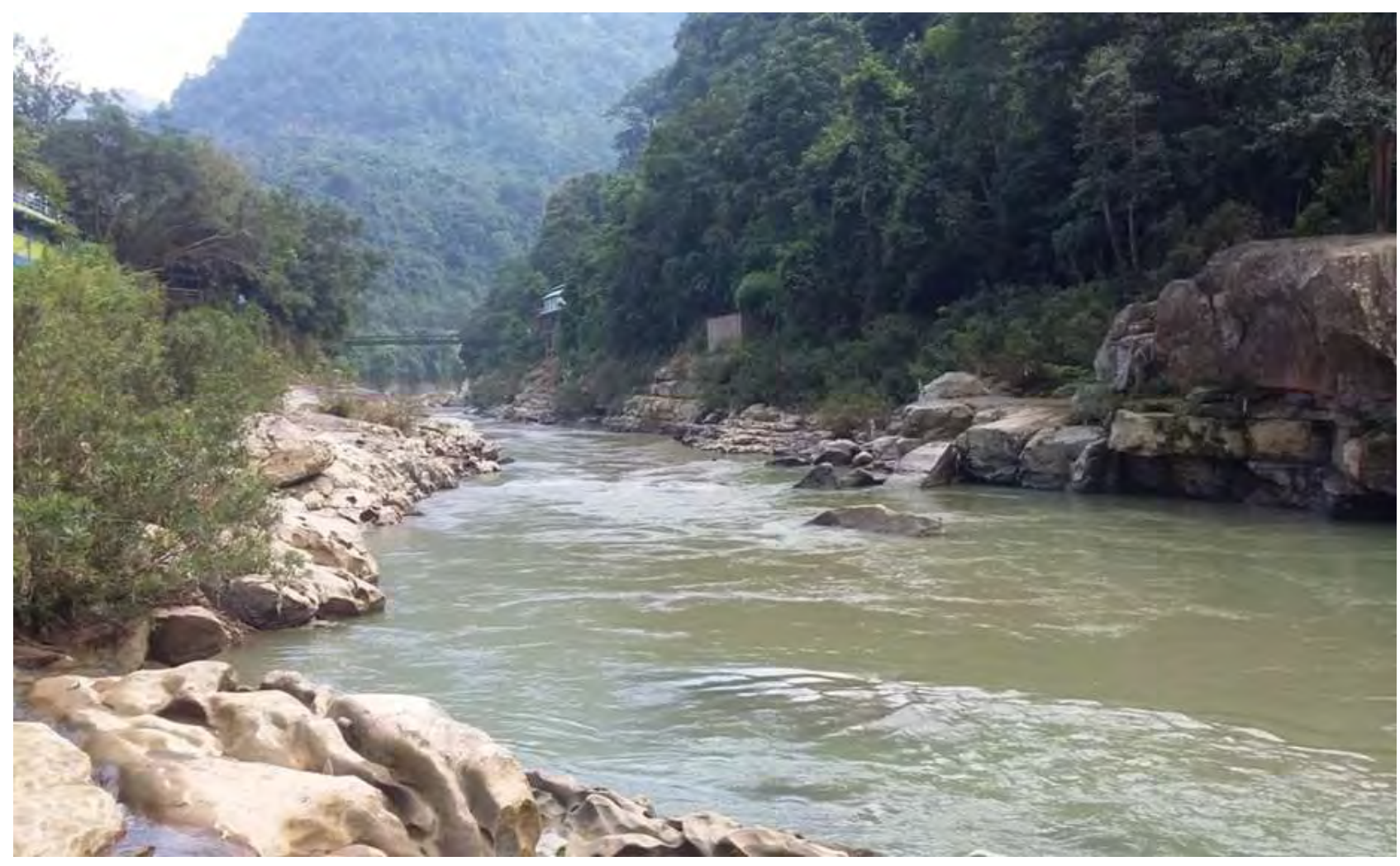

Figure 1: Study site - Tlawng river at Reiek Kai, Mizoram.

Needham et al. (1972).

\section{Study site}

The present study was undertaken in Tlawng river at Reiek Kai (Figure 1). Tlawng river is one of the longest rivers in Mizoram measuring $234 \mathrm{~km}$ in length (Pachuau, 2009). It originates at Zopui Hill (near Zobawk), $8 \mathrm{~km}$ east of Lunglei at an elevation of $1395 \mathrm{~m}$. After the confluence with Tut and Teirei rivers, it eventually enters Cachar district, Assam.

\section{RESUlTS AND DISCUSSIONS}

A total of 16 genera of phytoplanktons belonging to 10 orders and 5 groups were reported from the study site (Table 1). The phytoplankton belongs to Chlorophyceae, Zygnematophyceae, Cyanophyceae, Bacillariophyceae and Ulvophyceae (Figure 2). Bacillariophyceae was the most dominant group and constitutes $60 \%$ of the total phytoplankton encountered during the study period. Navicula belonging to Bacillariophyceae of order Naviculales was the most abundant and constitutes $41 \%$ of the total phytoplankton. Majority of the Navicula were encountered during the month of December. The second most abundant phytoplanktons, the Rivularia belonging to Cyanophyceae of order Nostocales were represented by 104 specimens and constitutes $15 \%$ of the group. The least dominant genera were that of Hydrodictyon, Desmidium, Nostoc and Pinnularia, represented by less than 10 specimen each. Navicula and Diatoma belonging to Bacillariophyceae were the only phytoplankton that were encountered throughout the study period, i.e from August 2017 to May 2018. Occurrence of maximum number of Navicula may reflect the healthy and less likely polluted nature of Tlawng river at Reiek Kai as Bacillariophyceae prefers unpolluted water bodies, thereby acting as an indicator of water pollution.

According to Trivedi et al. (1985), clean water bodies generally consists of Bacillariophyceae dominated flora. Summer season harbours maximum number of phytoplanktons where $38 \%$ of the total phytoplankton were collected. Least number of phytoplanktons were encountered during spring season. This is not in accordance with the findings of Latha et al. (2014) who reported maximum phytoplanktons blooms in the coastal waters along the East Coast of India during spring season. They attributed this to the thermal stratification at the break of spring leading to phytoplankton bloom. The result is also not in accordance with the findings of Lalhmingliani and Jessai (2016) where maximum phytoplankton were reported during spring season in Tam Dil, Mizoram.

The present study reported a total of 5 groups of zooplanktons belonging to 7 orders and 7 genera. (Table 2). The zooplankton group encountered were Copepoda, Tubulinea, Branchiopoda, Rotifera and Nematoda (Figure 


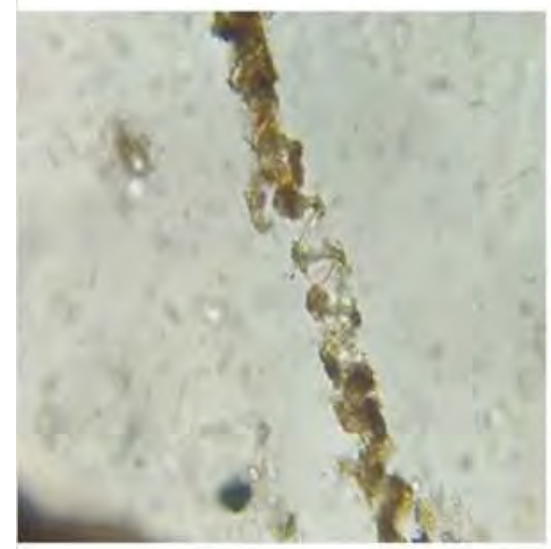

Spirogyra

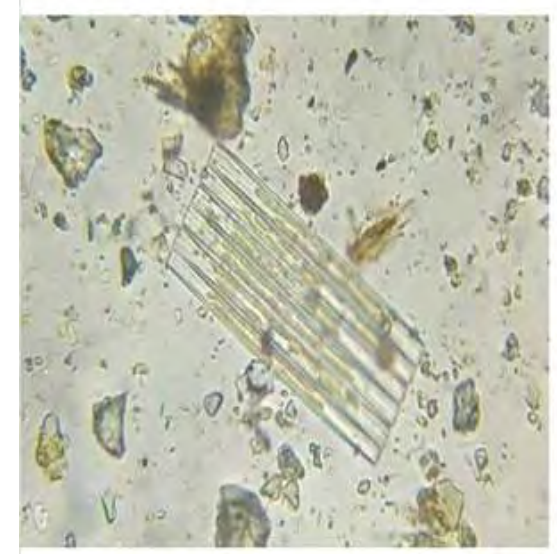

Meridion

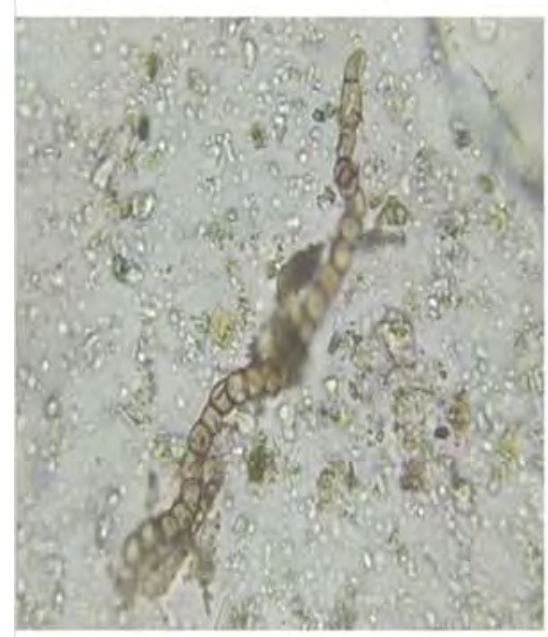

Anabaena

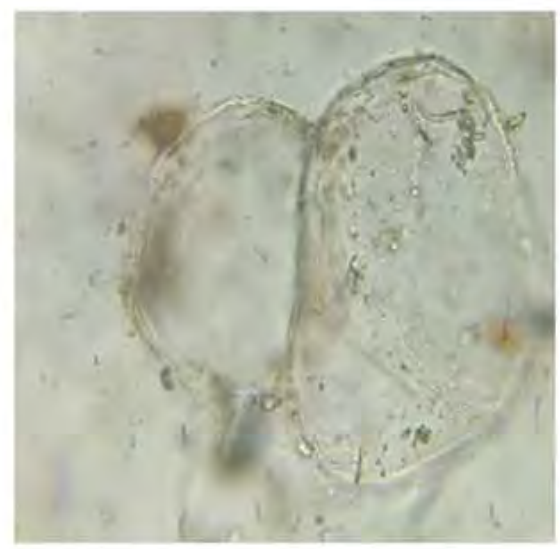

Cosmarium

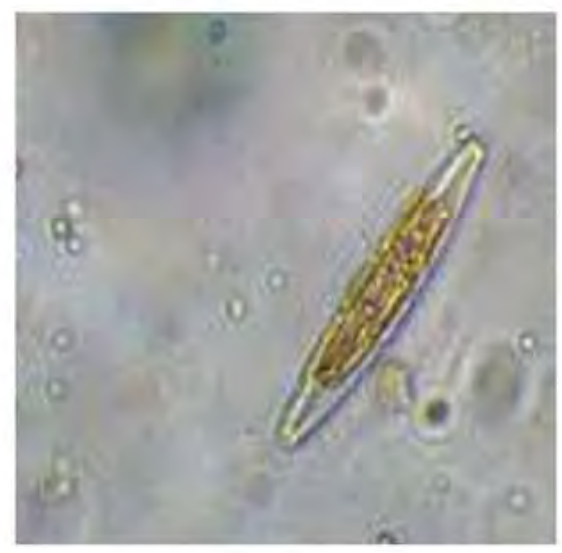

Navicula

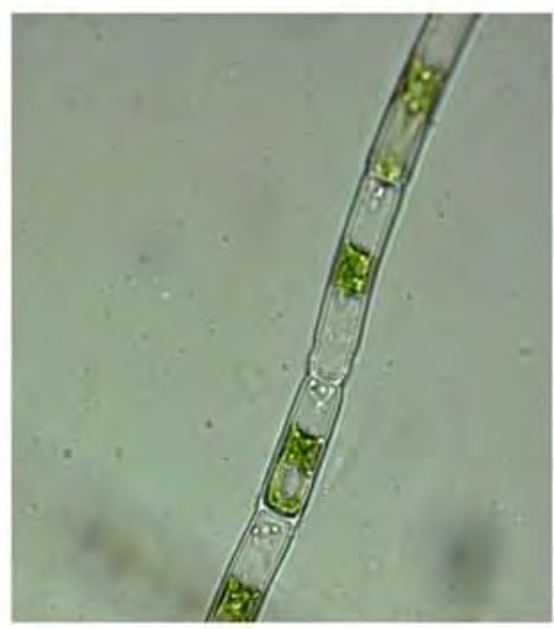

Oedogonium

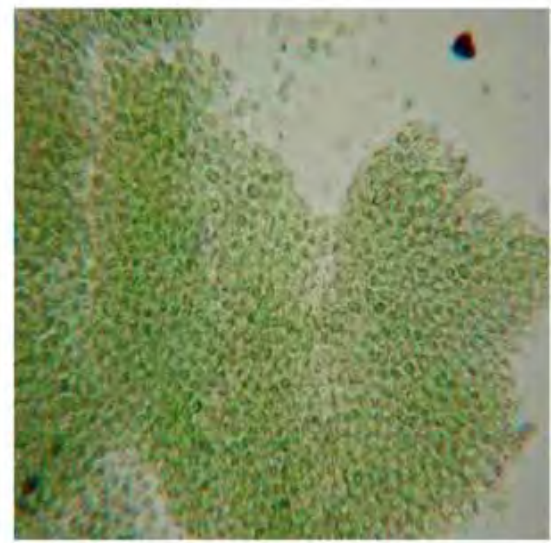

Microcystis

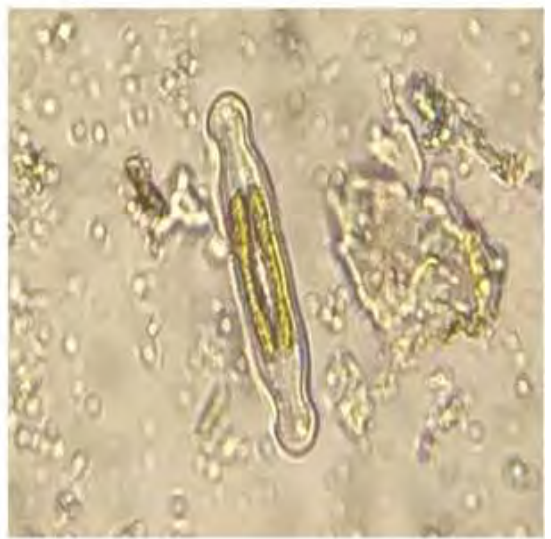

Diatom

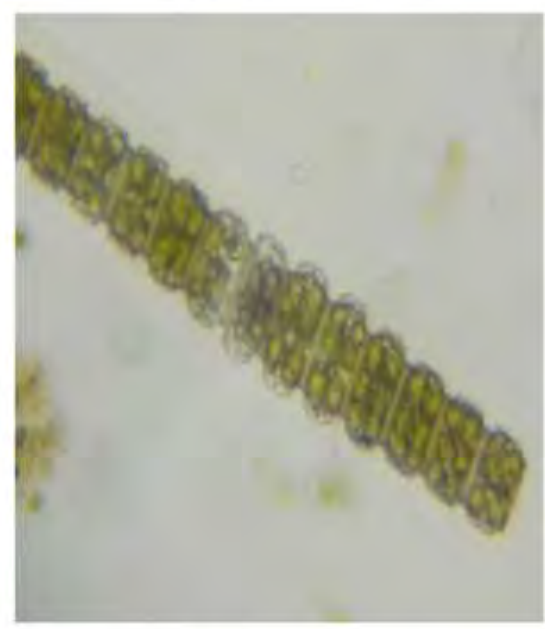

Desmidium

Figure 2: Phytoplanktons of Tlawng river at Reiek kai. 


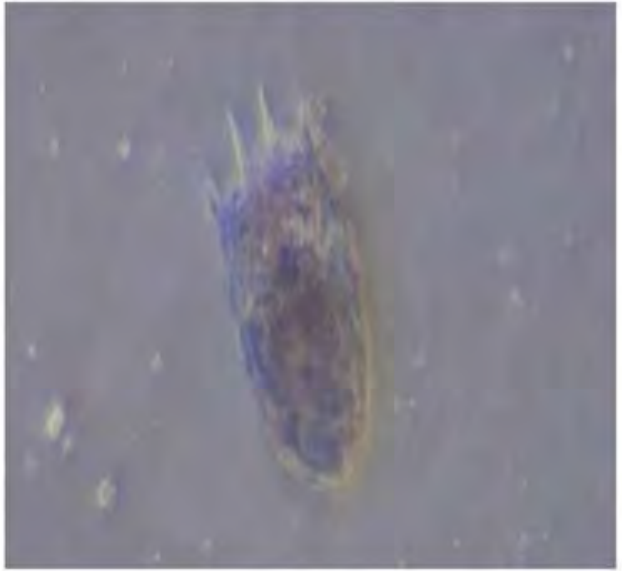

Keratella

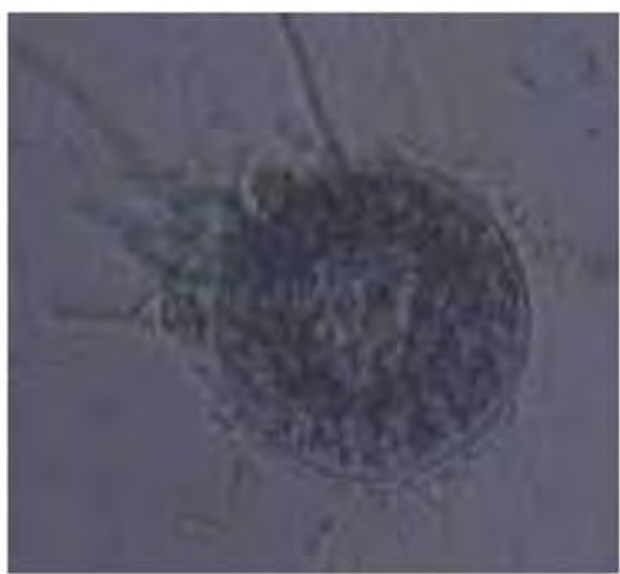

Arcella

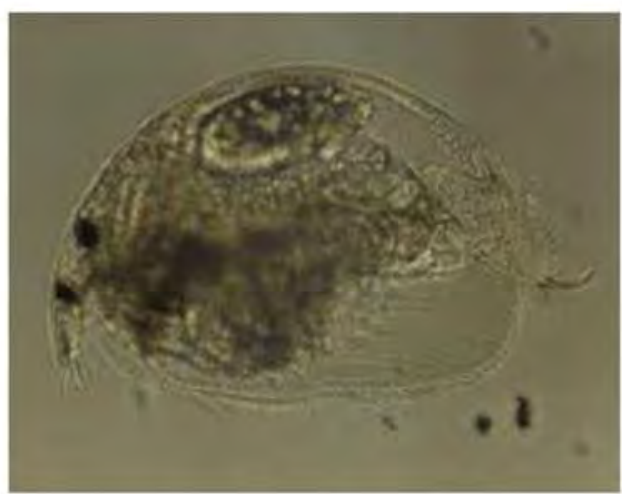

Chydorus

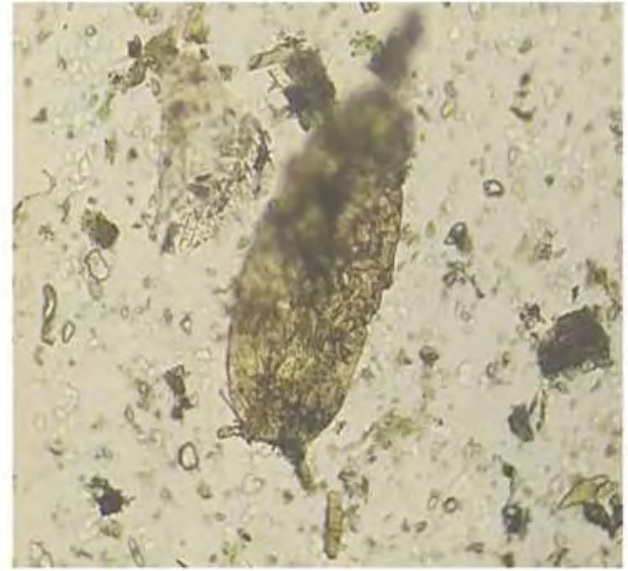

Cyclops

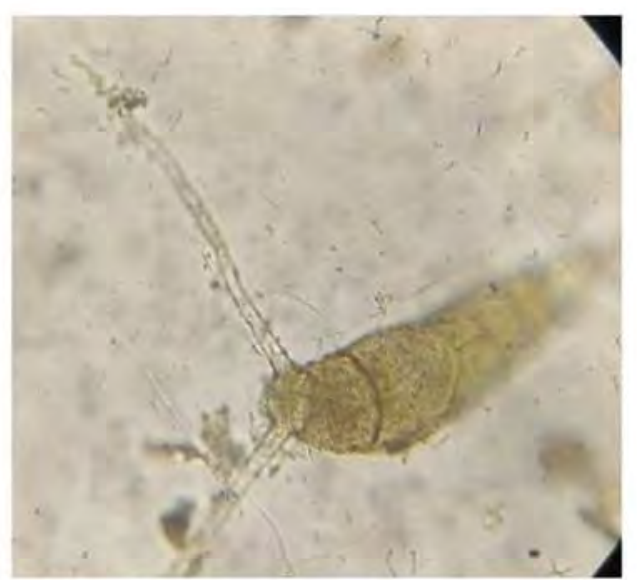

Calanoid

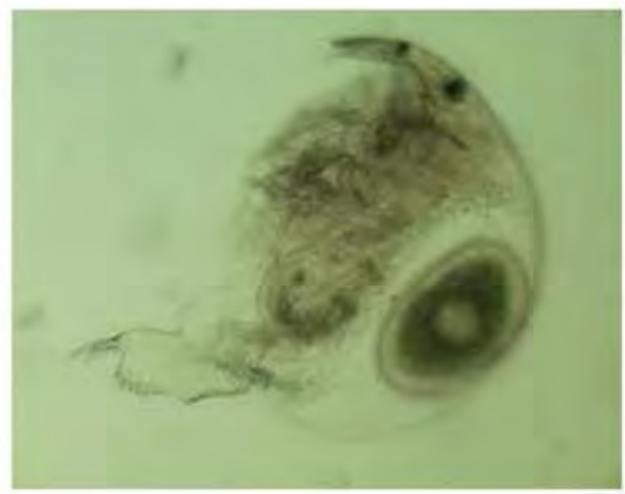

Alona

Figure 3: Zooplanktons of Tlawng river at Reiek kai. 
Table 1: List of phytoplanktons from the study site.

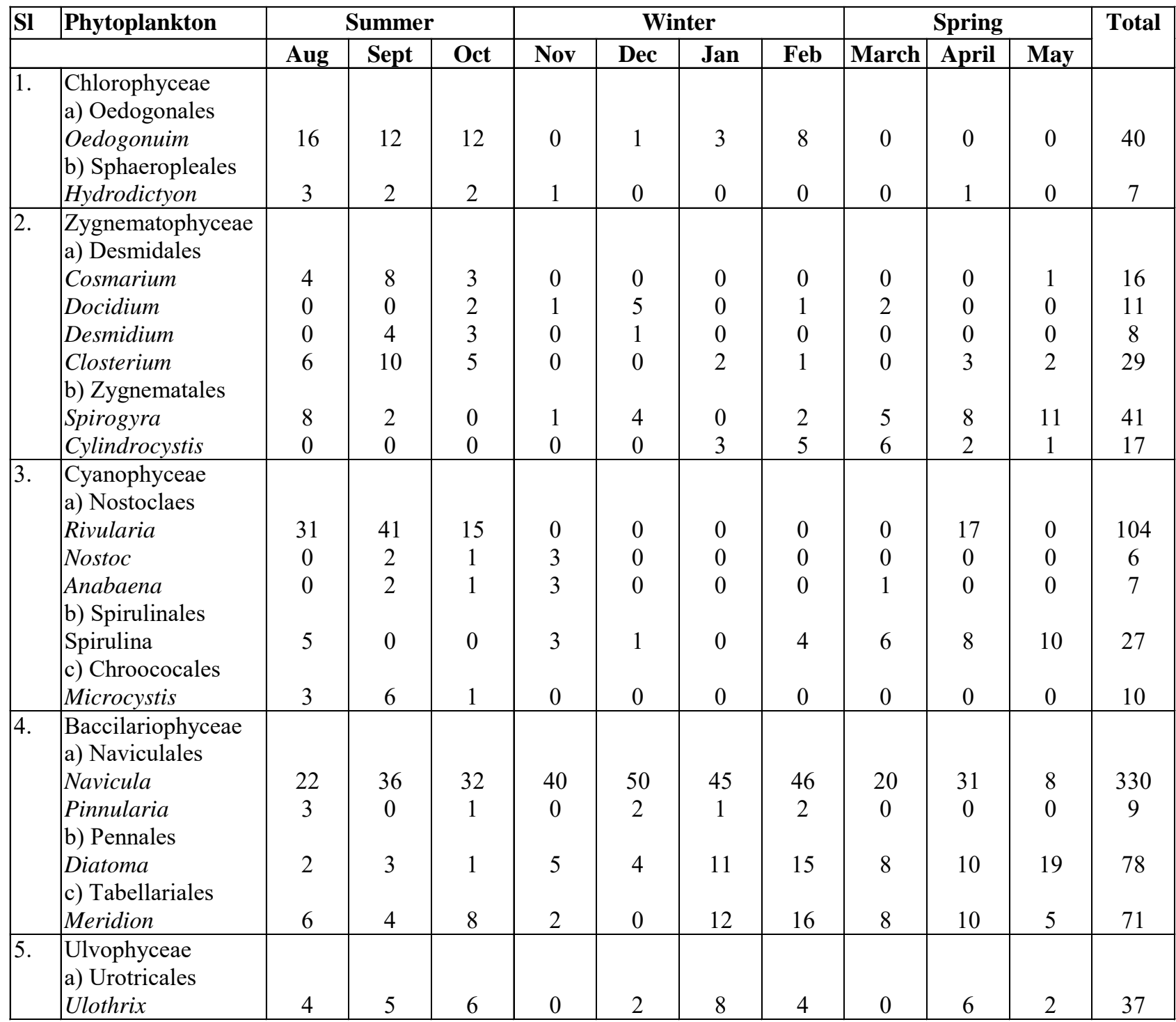

Table 2: List of zooplanktons from the study site.

\begin{tabular}{|c|c|c|c|c|c|c|c|c|c|c|c|c|}
\hline \multirow{2}{*}{$\begin{array}{l}\text { Sl. } \\
\text { No }\end{array}$} & \multirow[t]{2}{*}{ Zooplankton } & \multicolumn{3}{|c|}{ Summer } & \multicolumn{4}{|c|}{ Winter } & \multicolumn{3}{|c|}{ Spring } & \multirow[t]{2}{*}{ Total } \\
\hline & & Aug & Sept & Oct & Nov & Dec & Jan & Feb & Mar & April & May & \\
\hline 1. & $\begin{aligned} \text { Banchiopoda } \\
\text { a) Cladocera } \\
\text { Alona } \\
\text { b) Diplostraca } \\
\\
\text { Chydorus }\end{aligned}$ & $\begin{array}{l}2 \\
0\end{array}$ & $\begin{array}{l}3 \\
0\end{array}$ & $\begin{array}{l}2 \\
0\end{array}$ & $\begin{array}{l}5 \\
5\end{array}$ & $\begin{array}{l}0 \\
0\end{array}$ & 2 & $\begin{array}{l}8 \\
0\end{array}$ & $\begin{array}{l}4 \\
0\end{array}$ & $\begin{array}{l}1 \\
1\end{array}$ & $\begin{array}{l}1 \\
0\end{array}$ & $\begin{array}{l}28 \\
9\end{array}$ \\
\hline 2. & $\begin{array}{l}\text { Copepoda } \\
\text { (Maxillopoda) } \\
\text { a) Cyclopoda } \\
\text { Cyclops } \\
\text { b) Calanoida } \\
\text { Calanoid }\end{array}$ & $\begin{array}{l}0 \\
10 \\
\end{array}$ & $\begin{array}{r}0 \\
12 \\
\end{array}$ & $\begin{array}{l}1 \\
6 \\
\end{array}$ & $\begin{array}{l}8 \\
15 \\
\end{array}$ & $\begin{array}{l}13 \\
16 \\
\end{array}$ & $\begin{array}{l}2 \\
8\end{array}$ & $\begin{array}{l}3 \\
12 \\
\end{array}$ & $\begin{array}{l}5 \\
2\end{array}$ & $\begin{array}{l}1 \\
8 \\
\end{array}$ & $\begin{array}{l}0 \\
4 \\
\end{array}$ & $\begin{array}{l}33 \\
93 \\
\end{array}$ \\
\hline 3. & $\begin{array}{l}\text { Tubulinea } \\
\begin{array}{c}\text { a) Arcellinida } \\
\text { Arcella }\end{array}\end{array}$ & 2 & 1 & 3 & 2 & 0 & 0 & 0 & 0 & 0 & 0 & 8 \\
\hline 4. & 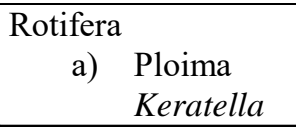 & 0 & 6 & 3 & 0 & 3 & 1 & 0 & 0 & 2 & 0 & 15 \\
\hline 5. & Nematode worms & 4 & 2 & 5 & 0 & 3 & 7 & 6 & 0 & 0 & 0 & 27 \\
\hline
\end{tabular}


3). The Copepoda constituting 59\% of the total zooplankton population were found to be the most dominant group encountered during the sampling period. According to Kalff (2002), this probably indicates better habitat condition and greater availability of food in terms of detritus, bacteria and phytoplankton for the Copepoda in the study area. Trivedy (1985) also states that high occurence of Copepoda may be attributed to the availability of bacteria which serves as a food source for small crustaceans or early stages of small crustaceans. The least dominant group among the zooplankton was Tubulinea constituting only $4 \%$ of the total zooplankton population.

Calanoid belonging to Copepoda of order Calanoida was the most abundant genera and constitute $44 \%$ of the total zooplankton population. According to Ferdous and Muktadir (2009), the dominance of Calanoid in the present study may indicates a relatively nutrient rich condition of the study site. The calanoid were found most abundantly during the month of December. Cyclops, the second most abundant genera belonging to Copepoda of order Cyclopoida constitutes 15\% of the zooplankton population. The two least abundant genera were Arcella and Chydorus, belonging to Tubulinea and Branchiopoda respectively. Unlike the phytoplankton which were encountered mostly during the summer season, maximum number of zooplanktons were encountered during the winter season. This may be attributed to the approach of spring season which favours the growth and reproduction of the Copepods and the Branchiopods (Kiørboe and Hirst, 2008). Similar observation was made by Pachuau et al. (2013) on Khawiva reservoir where maximum zooplanktons were reported during December and minimum during the month of May. The present result is also in line with the report of Lalhmingliani and Freddy (2017) from Serlui 'B' dam, Mizoram where maximum zooplanktons were reported during the winter season. However, the dominance of zooplankton species is highly variable in different types of water body according to nutrient levels, predator and other environmental factors which then affects the other biotic components of the ecosystem (Ismail and Zaidin, 2015).

The findings indicate that Tlawng river at Reiek Kai is a good, nutrient rich ecosystem, likely to be less polluted with an ability to sustain tremendous diversity of flora and fauna. However, the short period of sampling is not sufficient to reflect the real status of the study site and the present findings is expected to provide a better insight and understanding of the study site with respect to diversity of planktons and water quality status.

\section{REFERENCES}

Biligrami, K.S. (1988). Biological monitoring of rivers, problems and prospects in India. Aquatic Ecotoxicology, 245-250.

Davies, C.C. (1955). The M arine and Freshwater Plankton. Constable and Company Ltd., London, p. 539.
Edmondson, W.T. (1959). Freshwater Biology $\left(2^{\text {nd }}\right.$ Edition). John Wiley and sons, Inc., N.Y., pp. 1-412.

Ferdous, Z., Muktadir, A.K.M. (2009). A review: potentiality of zooplankton as bioindicator. American Journal of Applied Sciences, 6 (10), 1815-1819.

Fristch, F.E. (1935). The Structure and Reproduction of Algae Vol 1. Cambridge, pp. 1-791.

Ismail, A.H., Zaidin, S.A. (2015). A comparative study of zooplankton diversity and abundance from three different types of water body. Proceedings of the 2nd International Conference on Agriculture, Environment and Biological Sciences, (ICAEBS'15) August 16-17, Bali, Indonesia, pp. 37-41.

Kalff, J. (2002). Limnology Inland Water Ecosystems. $2^{\text {nd }}$ Edition. Prentice Hall Publications, New Jersey, USA, p. S92.

Kiørboe, T., Hirst, A.G. (2008). Optimal development time in pelagic Copepods. Marine Ecological Programme, $367,15-22$.

Lalhmingliani, E., Freddy, L. (2017). A preliminary assessment on the plankton diversity of Serlui ' $B$ ' dam in Mizoram, Northeast India. Science Vision, 17 (4), 238246.

Lalhmingliani, E., Ralte, J.L.B. (2016). Preliminary assessment of plankton diversity of Tam Dil in Mizoram, North East India. Proceedings of the Mizoram Science Congress, pp. 39-42.

Latha, T.P., Rao, K.H., Amminedu, E., Nagamani, P.V., Choudhury, S.B., Lakshmi, P. N., Dutt, C.B.S., Dhadwal, V.K. (2014). Seasonal variety of Phytoplankton blooms in the coastal waters along the East Coast of India. The International Archives of the Photogrammetry, Remote Sensing and Spatial Information Sciences, 8, 1065-1071.

Needham, J.G., Needham, P.R. (1972). A Guide to the Study of Freshwater Biology ( $5^{\text {th }}$ Edition). Holden-Day, Inc., Sansone Street, San Francisco, C.A., pp. 105.

Pachuau, L., Sharma, B.K. (2013). Zooplankton diversity of a sub-tropical reservoir of Mizoram, Northeast India. Opuscula Zoologica Budapest, 44(1), 47-60.

Pachuau, R. (2009) Mizoram. A study in Comprehensive Geography. Northern Book Centre, Ansari Road, Daryaganj, New Delhi, India, pp. 41-54.

Ramanibai, R., Ramachandran, R. (2013). Diatoms as proxy for paleo studies: A case study from KRP. Journal of the Geological Society of India, 90, 159-168

Thurman, H.V. (1997). Introductory Oceanography. New Jersey, USA: Prentice Hall College.

Trivedy, R.K., Garud, J.M. and Goel, P.K. (1985). Studies on chemistry and phytoplankton of freshwater bodies in Kolhapur with special reference to human activity. Poll. Res, 4(1), 25-44. 